\title{
PENERAPAN NAÏVE BAYES UNTUK PREDIKSI KELAYAKAN KREDIT
}

\author{
Dedy Ahmad Kurniawan"), Danny Kriestanto ${ }^{2)}$ \\ Teknik Informatika, STMIK AKAKOM \\ e-mail: dedyahmad.akakom10@gmail.com ${ }^{1)}$,danny@akakom.ac.id ${ }^{2)}$
}

\begin{abstract}
ABSTRAK
Dalam dunia perbankan, pemberian kredit kepada nasabah adalah kegiatan rutinyang mempunyai resiko tinggi. Dalam pelaksanaannya, kredit yang bermasalah (kredit macet) sering terjadi akibat analisis kredit yang tidak hati-hati atau kurang cermat dalam proses pemberian kredit, maupun dari karakter nasabah yang tidak baik. Untuk mencegah terjadinya kredit macet, diperlukan adanya peramalan akurat yang salah satunya menggunakan teknologi di bidang data mining.

Dengan menggunakan teknologi di bidang data mining yang mengoptimasi proses pencarian informasi prediksi dalam basis data yang besar, serta menemukan pola-pola yang tidak diketahui sebelumnya.Nä̈ve Bayes memprediksi probabilitas di masa depan berdasarkanpengalaman di masa sebelumnya dengan mempelajari korelasi hipotesis yang merupakan label kelas yang menjadi target pemetaan dalam klasifikasi dan evidence yang merupakan fitur-fitur yang menjadi masukan dalam model klasifikasi.

Pengolahan data berbasis data mining tersebut diharapkan dapat digunakan sebagai alat bantu dalam memprediksikan kelayakan kredit yang memperkirakan layak atau tidaknya pemohon atau nasabah untuk diberikan kredit.
\end{abstract}

Kata kunci: Data Mining, Nä̈ve Bayes, Prediksi kelayakan kredit

\section{ABSTRACT}

In banking business, lending a money is a routine that consists of high risks. By giving a lend to a person, a bank or an organization that have authority to to do that can lead to a bad credit because of a bad or recklessness indata analysis. In order to prevent these things to occur, a good forecasting tool is needed.

The using of data mining techniques in searching process of a huge amount of data to extract information can be done quickly in order to find a good prediction of money lending, and also to find unusual patterns that cannot be seen before. Nä̈ve Bayes can predict probability based on previous experiences (data) by studying hypothesis as the target of the classification and evidence as input features in classification model.

The implemented data mining application can be used as a tool to predict the creditworthiness of a prospective borrower.

Keywords: Data Mining, Nä̈ve Bayes, Creditworthiness prediction

\section{Pendahuluan}

$\mathrm{D}$ i dalam dunia perbankan pemberian kredit kepada nasabah adalah kegiatan rutin yang mempunyai resiko tinggi. Dalam pelaksanaannya, kredit yang bermasalah (kredit macet) sering terjadi akibat analisis kredit yang tidak hati-hati atau kurang cermat dalam proses pemberian kredit, maupun dari karakter nasabah yang tidak baik. Untuk mencegah terjadinya kredit macet, seorang analisis kredit perbankan harus mampu mengambil keputusan yang tepat untuk menerima ataupun menolak pengajuan kredit. Untuk mengetahui kelayakan kredit di masa mendatang, diperlukan adanya peramalan yang akurat yang salah satunya menggunakan teknologi di bidang data mining.

Dengan menggunakan teknologi di bidang data mining yang mengoptimasi proses pencarian informasi prediksi dalam basis data yang besar, serta menemukan pola-pola yang tidak diketahui sebelumnya. Maka identifikasi pola data dari sistem penentuan pemberian kredit dapat dilakukan dengan pendekatan probabilitas bersyarat. Berdasarkan kemampuan belajar yang dimilikinya, maka data mining dapat dapat dioptimasi untuk menemukan pola dimasa lalu dan mencari suatu fungsi yang akan menghubungkan pola data masa lalu dengan keluaran yang diinginkan. Naïve Bayes memprediksi probabilitas di masa depan berdasarkan pengalaman di masa sebelumnya. Dengan mempelajari korelasi hipotesis yang merupakan label kelas yang menjadi target pemetaan dalam klasifikasi, dan evidence yang merupakan fitur-fitur yang menjadi masukan dalam model klasifikasi.

Data mining adalah proses yang mempekerjakan satu atau lebih teknik pembelajaran komputer (machine learning) untuk menganalisa dan mengekstraksi pengetahuan (knowledge) secara otomatis [1].

Menurut [2], data mining adalah kegiatan yang meliputi pengumpulan, pemakaian data historis untuk menemukan keteraturan pola atau hubungan dalam set data yang berukuran besar.

Dengan adanya aplikasi pengolahan data berbasis data mining tersebut diharapkan dapat digunakan sebagai alternatif dan alat bantu dalam memprediksikan resiko kelayakan kredit yang memperkirakan layak atau tidaknya pemohon atau nasabah untuk diberikan kredit, yang dalam penelitian ini digunakan BMT Beringharjo, Yogyakarta sebagai studi kasusnya. 
Adapun perbedaan tinjauan pustaka yang dijadikan sebagai acuan dalam penelitian ini adalah seperti yang tampak pada Tabel I.

TABEL I

PERBANDINGAN TINJAUAN PUSTAKA

\begin{tabular}{|c|c|c|c|c|}
\hline Referensi & Objek & Masukan & Metode & $\begin{array}{c}\text { Keluaran } \\
\end{array}$ \\
\hline [3] & Klasifikasi premi asuransi & Data Nasabah & Naïve Bayes & $\begin{array}{l}\text { Lancar, kurang lancar, atau tidak } \\
\text { lancar }\end{array}$ \\
\hline [4] & $\begin{array}{l}\text { Koperasi Kara Audita } \\
\text { Perwakilan BPKP } \\
\text { Yogyakarta }\end{array}$ & Data Nasabah & Naïve Bayes & $\begin{array}{l}\text { Diterima, dipertimbangkan, atau } \\
\text { ditolak }\end{array}$ \\
\hline [5] & $\begin{array}{l}\text { BMT Beringharjo, } \\
\text { Yogyakarta }\end{array}$ & $\begin{array}{l}\text { Data historis nasabah } \\
\text { yang telah diakui } \\
\text { kelayakannya }\end{array}$ & Back Propagation & Diterima atau ditolak \\
\hline $\begin{array}{l}\text { Yang } \\
\text { diajukan }\end{array}$ & $\begin{array}{l}\text { BMT Beringharjo, } \\
\text { Yogyakarta }\end{array}$ & Data Nasabah & Naïve Bayes & Layak atau Tidak Layak \\
\hline
\end{tabular}

\section{METODE}

\section{A. Metode Penelitian}

Adapun metode penelitian yang diterapkan secara berurutan adalah sebagai berikut:

\section{1) Pengumpulan Data}

Data penelitian diperoleh dengan melakukan survei dan juga meminta langsung kepada pihak pengelola BMT Beringharjo Yogyakarta.

2) Analisis Kasus

Analisis dilakukan dengan membandingkan hasil pertimbangan pihak BMT Beringharjo seperti ditunjukkan pada Tabel II, kemudian diterapkan dalam aplikasi dengan menggunakan Naïve Bayes.

3) Perancangan Aplikasi

Adapun perancangan aplikasi ini akan dibuat berbasis Java dengan bantuan perangkat lunak Netbeans. Oleh karena itu, desain perancangan dari aplikasi ini akan menggunakan UML.

4) Pengujian Aplikasi

Pengujian dilakukan dengan membandingkan hasil perhitungan manual dengan hasil perhitungan aplikasi dan dilihat persentase tingkat kesalahannya.

\section{B. Kebutuhan Input}

Data masukan yang dibutuhkan dalam sistem ini adalah data pengajuan kredit yaitu jaminan, total penghasilan, pinjaman lain, total pengeluaran, nominal kredit, status rumah, dan tempo pengembalian. Data pengajuan kredit ini nantinya akan dijadikan data untuk proses training, dimana data tersebut sudah diklasifikasikan sebelumnya sesuai dengan kelayakan kreditnya yaitu layak maupun tidak layak. Adapun sampel data training yang digunakan dapat dilihat pada Tabel II.

\section{Kebutuhan Output}

Kebutuhan keluaran atau output yang dihasilkan dari sistem ini adalah hasil prediksi data melalui proses training dan testing yang layak maupun tidak layak. Proses testing data dilakukan setelah adanya hasil dari proses training data untuk menentukan nilai posterior probability terhadap data baru yang diujikan.

Nilai tersebut merupakan nilai dari probabilitas akhir dari data yang diujikan sesuai dengan kelasnya yang masuk kedalam kelas layak maupun tidak layak. Dari data tersebut nantinya akan dibandingkan hasil probabilitas akhir antara kelas layak dana tidak layak. Nilai probabilitas akhir yang lebih besar akan dijadikan sebagai nilai akhir sekaligus sebagai keputusan apakah pengajuan kredit layak ataupun tidak layak.

\section{Perancangan Sistem}

Pemodelan yang digunakan untuk membangun sistem ini adalah pemodelan dengan menggunakan UML (Unified Modelling Language) yang meliputi antara lain usecase diagram, activity diagram, dan class diagram.

\section{1) Usecase Diagram}

Usecase diagram yang digunakan dalam aplikasi ini dapat dilihat pada Gambar 1.

\section{2) Activity Diagram Training}

Activity diagram training ini merupakan gambaran dari sistem melakukan proses training terhadap data. Adapun Activity diagram training dapat dilihat pada Gambar 2.

3) Activity Diagram Testing

Activity diagram testing ini merupakan gambaran dari sistem melakukan proses testing terhadap data. Adapun perancangan Activity diagram testing dapat dilihat pada Gambar 3. 
TABEL II

SAMPEL DATA TRAINING

\begin{tabular}{ccrrrrrrr}
\hline \hline No & Jaminan & $\begin{array}{c}\text { Total } \\
\text { Penghasilan }\end{array}$ & $\begin{array}{c}\text { Pinjaman } \\
\text { Lain }\end{array}$ & $\begin{array}{c}\text { Total } \\
\text { Pengeluaran }\end{array}$ & $\begin{array}{c}\text { Nominal } \\
\text { Kredit }\end{array}$ & $\begin{array}{c}\text { Status } \\
\text { Rumah }\end{array}$ & $\begin{array}{c}\text { Tempo } \\
\text { Pengembalian }\end{array}$ & $\begin{array}{c}\text { Kelayakan } \\
\text { Kredit }\end{array}$ \\
\hline $\mathbf{1}$ & Spd mtr & 5.000 .000 & 500.000 & 1.500 .000 & 3.000 .000 & Kontrak & 3 & Layak \\
$\mathbf{2}$ & Tab & - & - & 1.070 .000 & 2.500 .000 & Mp & 3 & Layak \\
$\mathbf{3}$ & Tab & - & - & 215.000 & 700.000 & Mp & 3 & Layak \\
$\mathbf{4}$ & Mobil & - & - & 3.000 .000 & 10.000 .000 & Mp & 24 & Layak \\
$\mathbf{5}$ & Spd mtr & - & - & 1.530 .000 & 5.000 .000 & Kontrak & 12 & Layak \\
$\mathbf{6}$ & Shm & - & - & 7.107 .500 & 140.000 .000 & Kontrak & 24 & Tidak layak \\
$\mathbf{7}$ & Spd mtr & - & - & 500.000 & 10.000 .000 & Kontrak & 12 & Tidak layak \\
$\mathbf{8}$ & Mobil & 500.000 & 500.000 & 2.500 .000 & 25.000 .000 & Mp & 6 \\
$\mathbf{9}$ & Shm & 200.000 & 200.000 & 750.000 & 20.000 .000 & Mp & 6 & Tidak layak \\
$\mathbf{1 0}$ & Spd mtr & 1.500 .000 & 1.500 .000 & 1.000 .000 & 45.000 .000 & Mp & 6 & Tidak layak \\
Tidak layak \\
\hline \hline
\end{tabular}

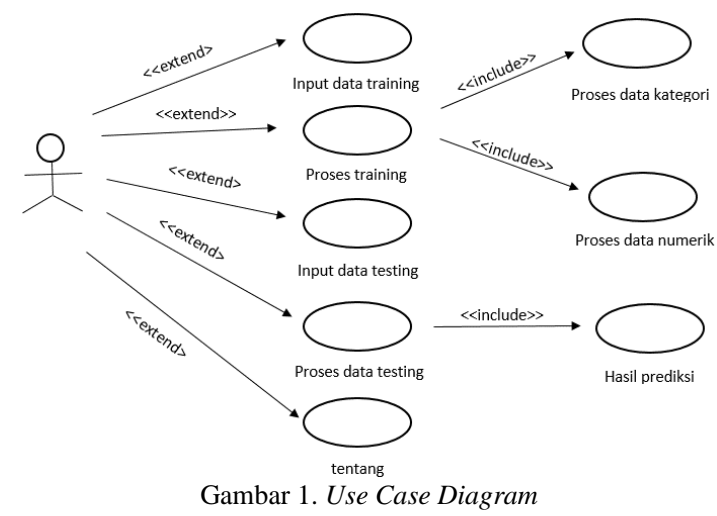

\section{4) Activity Diagram Naïve Bayes}

Gambar 4 merupakan gambaran dari keseluruhan proses yang dilakukan oleh metode Naïve Bayes. Proses ini meliputi dari awal perhitungan yang dilakukan ketika proses training data hingga proses prediksi data yang baru (data testing). Jika data berupa data kategori, maka dapat langsung dihitung probabilitas awalnya. Jika data berupa numerik maka akan dihitung terlebih dahulu mean, standar deviasi dan variansi dari tiap parameter data numerik. Setelah semua data dihitung nilai mean, standar deviasi dan variansi menggunakan rumus diatas, maka selanjutnya akan dihitung nilai probabilitas awal menggunakan rumus distribusi Gaussian. Dari data hasil perhitungan data yang berupa kategori dan numeric maka akan dijumlahkan berdasarkan kelas kelayakannya (layak atau tidak layak) untuk mendapatkan probailitas akhir dari setiap kelas. Kemudian dari nilai probabilitas akhir tiap kelas tersebut akan dibandingkan dari keduanya. Nilai probabilitas akhir yang lebih besar akan menjadi hasil akhir dari prediksi. Activity diagram yang diimplementasikan dalam penelitian ini dapat dilihat pada Gambar 4.

\section{5) Class Diagram}

Implementasi aplikasi ini menggunakan class diagram seperti tampak pada Gambar 5.

\section{HASIL}

Masukan data training dilakukan di borang data training, dan hasilnya tampak seperti pada Gambar 6. Borang data training difungsikan untuk memasukkan data-data yang telah ada sebelumnya. Hal penting yang dimasukkan pada borang ini adalah jaminan, penghasilan, nominal kredit yang diinginkan, status kepemilikan rumah, dan kelayakan. Tampilan yang sama juga dilakukan terhadap borang data testing, seperti yang tampak pada Gambar 7, dengan tambahan nilai probabilitas, dan hasil prediksi berupa penentuan layak atau tidak-nya kredit yang diajukan untuk diterima.

Proses pengujian pertama kali dilakukan terhadap 40 data dan diperoleh hasil 37 data yang diprediksi benar (sesuai dengan metode manual) dan 3 data yang diprediksi salah. Kemudian pada pengujian terhadap 200 data, dengan 160 data testing dan 40 data training diperoleh tingkat akurasi aplikasi dapat mencapai $92.5 \%$ dengan nilai error sebesar 7,5\%.

\section{PEMBAHASAN}

Berdasarkan hasil penelitian, ada perbedaan yang cukup signifikan terjadi ketika jumlah data yang diujikan cukup banyak. Dari hasil uji 40 data ditambah hingga menjadi 200 data peningkatan akurasi bertambah tidak signifikan. Namun, apabila dibandingkan dengan hasil [4] dari sisi jumlah kriteria yang digunakan, tingkat akurasi dari aplikasi yang dibangun meningkat dengan signifikan dari 70\% menjadi 92,5\% [4]. Adapun data yang 
digunakan oleh [4] adalah sebanyak 250 data yang dibagi atas 170 data training dan 80 data testing. Dari kedua hasil ini dapat disimpulkan bahwa tingkat akurasi aplikasi akan meningkat seiring dengan semakin banyaknya kriteria yang digunakan.

\section{SIMPULAN DAN SARAN}

Berdasarkan hasil pengujian yang telah dilakukan,maka dapat disimpulkan sebagai berikut:

1) Penerapan algoritma data mining menggunakan Naïve Bayes dapat dilakukan untuk memprediksi kelayakan kredit pada BMT Beringharjo Yogyakarta.

2) Akurasi data yang diperoleh dalam penelitian ini adalah sebesar $92,5 \%$ dengan error sebesar $7,5 \%$ dari 160 data yang digunakan untuk training dan 40 data untuk testing.

3) Semakin banyak kriteria yang digunakan dalam proses prediksi maka akurasi data akan semakin tinggi.

Adapun saran untuk penelitian selanjutnya adalah sebagai berikut:

1) Penelitian selanjutnya sebaiknya tetap menggunakan data yang sudah ada kelayakannya untuk kemudahan proses training data.

2) Diperlukan penelitian lebih lanjut mengenai hubungan kriteria dengan akurasi prediksi kelayakan kredit.

3) Data dan kriteria yang digunakan perlu ditambah untuk hasil akurasi prediksi yang lebih baik.

[1] Fajar Astuti Hermawati, Data mining, Andi, Yogyakarta, 2013

[2] Budi Santosa, Data mining: teknik pemanfaatan data untuk keperluan bisnis, Graha Ilmu, Yogyakarta, 2007

[3] Bustami, "Penerapan algoritma naïve bayes untuk mengklasifikasi data nasabah asuransi", Universitas Malikussaleh, Aceh, 2013

[4] Putri Wulandari, "Sistem penentuan kredit koperasi dengan menggunakan pendekatan metode naïve bayes pada studi kasus koperasi karya audita perwakilan BPKP Yogyakarta", STMIK AKAKOM, Yogyakarta, 2014

[5] Arif Rahman Bintoro," Implementasi jaringan syaraf tiruan dengan metode backpropagation untuk prediksi kelayakan kredit di BMT Beringharjo, STMIK AKAKOM, Yogyakarta, 2014

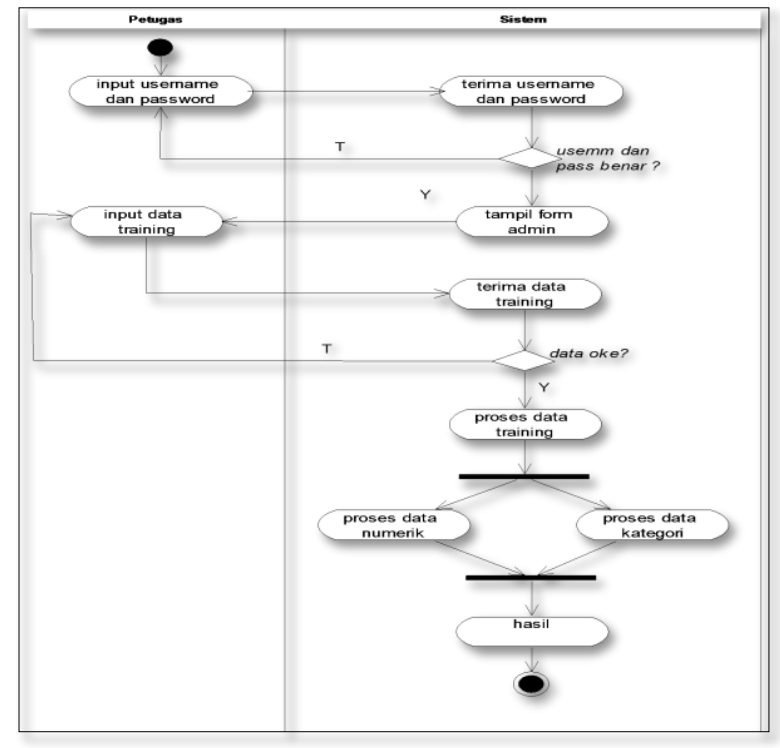

Gambar 2. Activity Diagram Training

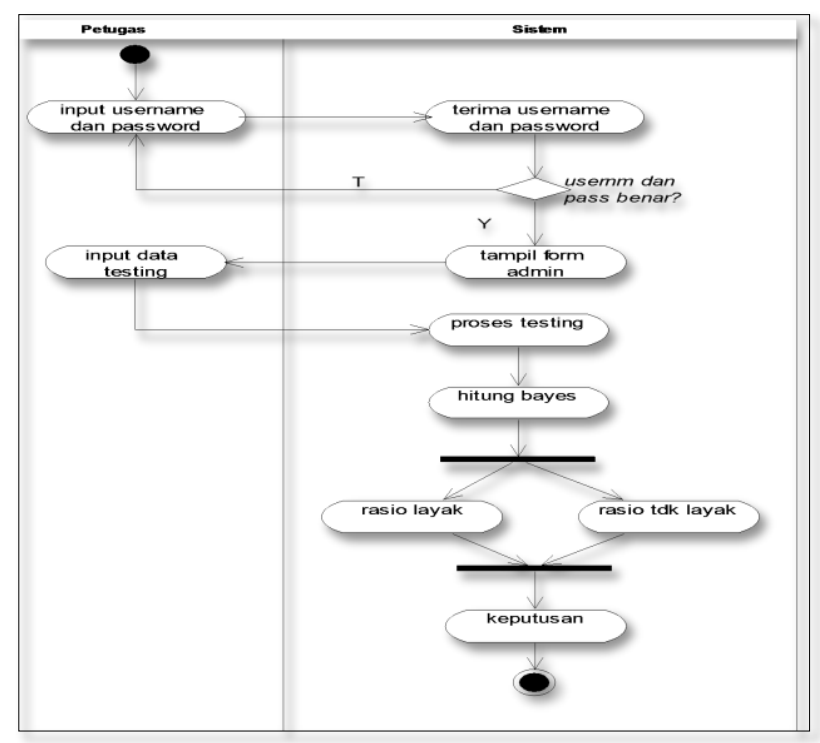

Gambar 3. Activity Diagram Testing 


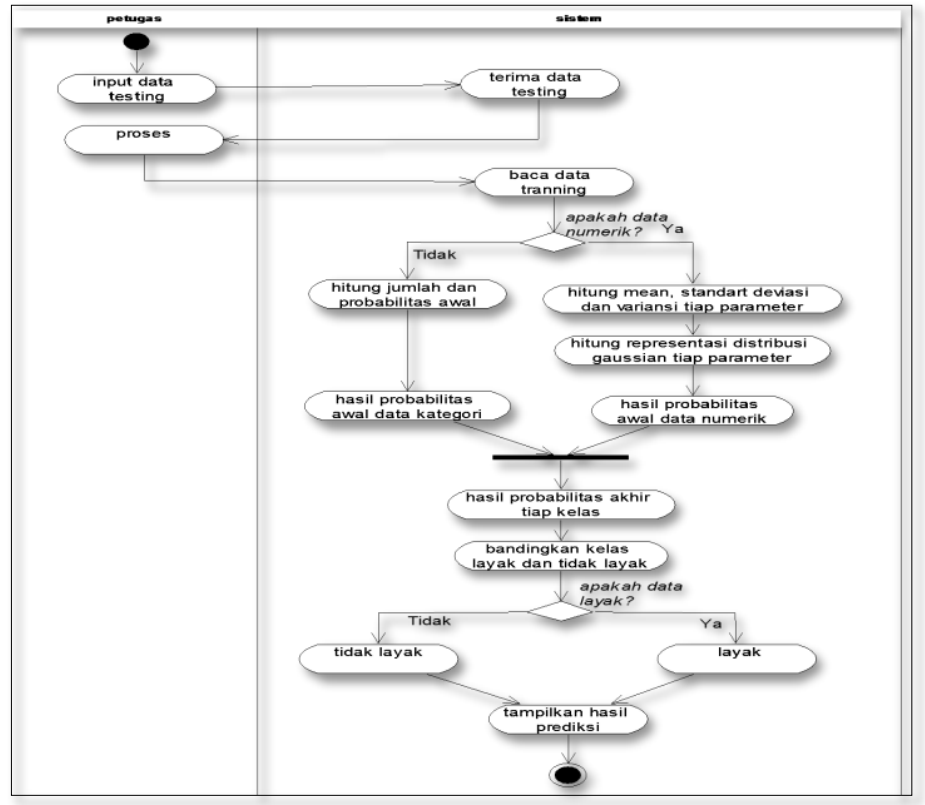

Gambar 4. Activity Diagram Naïve Bayes

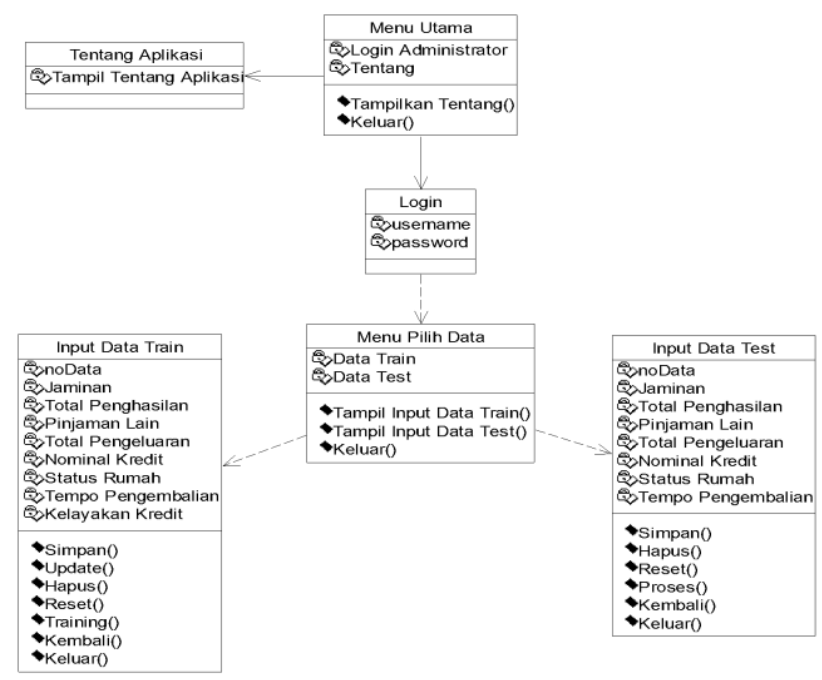

Gambar 5. Diagram Class

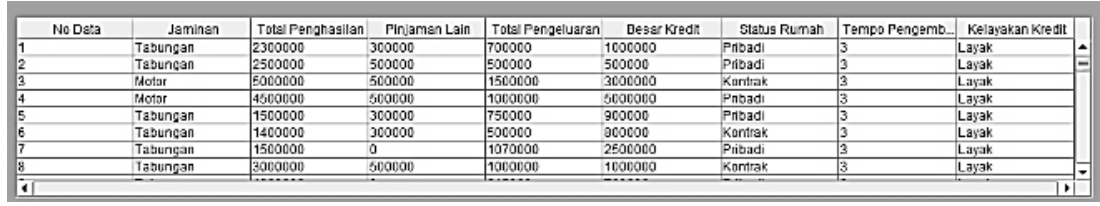

Gambar 6. Contoh Data Training

\begin{tabular}{|c|c|c|c|c|c|c|c|c|c|}
\hline No Data & Jaminan & Total Penghas.. & Pinjaman Lain & Total Pengelu... & Besar Kredit & Status Rumah & Tempo Penge... & Prediksi NBC & \\
\hline 2 & Motor & 5000000 & 10000000 & 4500000 & 45000000 & Pribadi & 24 & TidakLayak & - \\
\hline 3 & Motor & 2500000 & 15000000 & 1000000 & 10000000 & Kontrak & 12 & TidakLayak & \\
\hline 4 & Mobil & 2500000 & 5000000 & 2000000 & 7500000 & Pribadi & 24 & TidakLayak & \\
\hline 5 & Saham & 7000000 & 6000000 & 4000000 & 15000000 & Kontrak & 24 & TidakLayak & \\
\hline 6 & Motor & 1750000 & 5000000 & 1000000 & 5000000 & Pribadi & 6 & TidakLayak & $\equiv$ \\
\hline 7 & Motor & 3000000 & 5000000 & 2000000 & 15000000 & Pribadi & 12 & TidakLayak & \\
\hline 8 & Motor & 4750000 & 4500000 & 3000000 & 25000000 & Pribadi & 6 & TidakLayak & \\
\hline 9 & Motor & 5000000 & 5000000 & 3000000 & 40000000 & Pribadi & 3 & TidakLayak & \\
\hline 10 & Saham & 2000000 & 6000000 & 1000000 & 17000000 & Pribadi & 12 & TidakLayak & $=$ \\
\hline \multicolumn{2}{|c|}{ Probabilitas Layak } & \multicolumn{2}{|c|}{ 4. $301239432536737 \mathrm{E}-20$} & & & & & & \\
\hline \multicolumn{2}{|c|}{ Probabilitas Tidak Layak } & \multicolumn{2}{|c|}{$3.0561685853859835 E-18$} & & & & & & \\
\hline \multicolumn{2}{|l|}{ Hasil Prediksi } & \multicolumn{2}{|l|}{ Tidaklayak } & & & & & & \\
\hline
\end{tabular}

Gambar 7. Contoh Data Testing dan Nilai Probabilitas Kelayakan Kredit 